The International Journal of

Urologic History@

www.ijuh.org

\title{
It's pronounced "EE-lick": Milo Ellik, veteran, urologist, and inventor of the evacuator that bears his name
}

\author{
Nicole Matluck*, Bertie Zhang, Lee Richstone \\ From the Department of Urology (NM), New York Medical College, Valhalla, New York and the Department of Urology (BZ,LR), \\ Lenox Hill Hospital, New York, New York \\ *Correspondence: 40 Sunshine Cottage Road, Valhalla, New York; e-mail: nicolematluck@gmail.com
}

Introduction: The Ellik Evacuator is a commonly used tool in transurethral endoscopic surgery and a standard of care for the rapid removal from the bladder of resected tumor fragments, prostatic chips, or blood. Little is known, however, about the inventor of the Ellik evacuator, his urologic contributions, and how the evacuator came to be.

Sources: We contacted surviving descendants of Dr. Milo Ellik, and conducted interviews as part of an oral history project. Original medical equipment and personal belongings, provided by the family of Dr. Ellik, were analysed. Secondary source materials included published urologic articles and unpublished biographic information.

Results: Milo Ellik was born in Chicago in 1905 but was orphaned and put himself through college. He graduated from the University of lowa with an MD in 1932 and began residency under Nathan Alcock. Ellik conceived of the evacuator that bears his name as a resident, visiting the glass-blowing facility at the lowa University Hospital to construct the prototype. He published the results in a 1937 issue of the Journal of Urology but did not obtain a patent which was eventually procured by Bard in 1940.

Conclusions: Milo Ellik designed a major innovation in transurethral surgery as a resident in urology by constructing the first glass evacuator that bears his name. The Ellik family donated a large quantity of Dr. Ellik's inventions to the AUA's Didusch Museum for permanent storage and study.

Key Words: Milo Ellik, urologic technology, transurethral surgery, evacuator

$\mathrm{H}^{2}$ enry J. Bigelow (1818-1890), the renowned Boston surgeon, invented, among many things, a manual pump-based irrigator that allowed the urologist to evacuate the innumerable fragments of stone from the bladder obtained after blind lithotrity.(1) Popular in the 1870s and 1880s, the evacuator had a limited capacity to evacuate other products of transurethral surgery including prostatic chips, tumor, and blood that were becoming the modern routine by the 1930s. (2) By then, a young urology resident conceived of a single chambered tool which allowed for the cystoscopic irrigation of the bladder and the settling of stone or tissue fragments at the bottom of the irrigator that would not interfere with the irrigating cycles. Thus, the Ellik evacuator was born. There is little known about the inventor of this evacuator, Milo Ellik, despite his many urologic contributions throughout the 1930s-1950s. We wished to develop an intimate biographical portrait of Ellik and further study the development of the evacuator that bears his name.

International Journal of Urology(c) 2021

\section{SOURCES}

We contacted surviving family members of Dr. Milo Ellik and conducted telephone interviews which were immediately transcribed to a digital archive. We were provided photographs from the Ellik family and personal materials of Dr. Ellik including secondary school and college data as well as surgical instruments and their prototypes. We also consulted with secondary source materials including his published urologic works.

\section{RESULTS}

Born on October 15, 1905 in Chicago, Illinois to Pearl C. (nee) Frederick and Earl A. Ellik, Milo, who always pronounced his last name "EE-lik", was orphaned at a young age.(3) He was known as a studious and quiet child who spent his free time sketching and doodling. Ellik's 1925 Boone High School yearbook, The Scroll, featured his quirky illustrations throughout showcasing

https://doi.org/10.53101/IJUH71217 Vol. I (i), 37-41, July 2021 Electronically distributed 


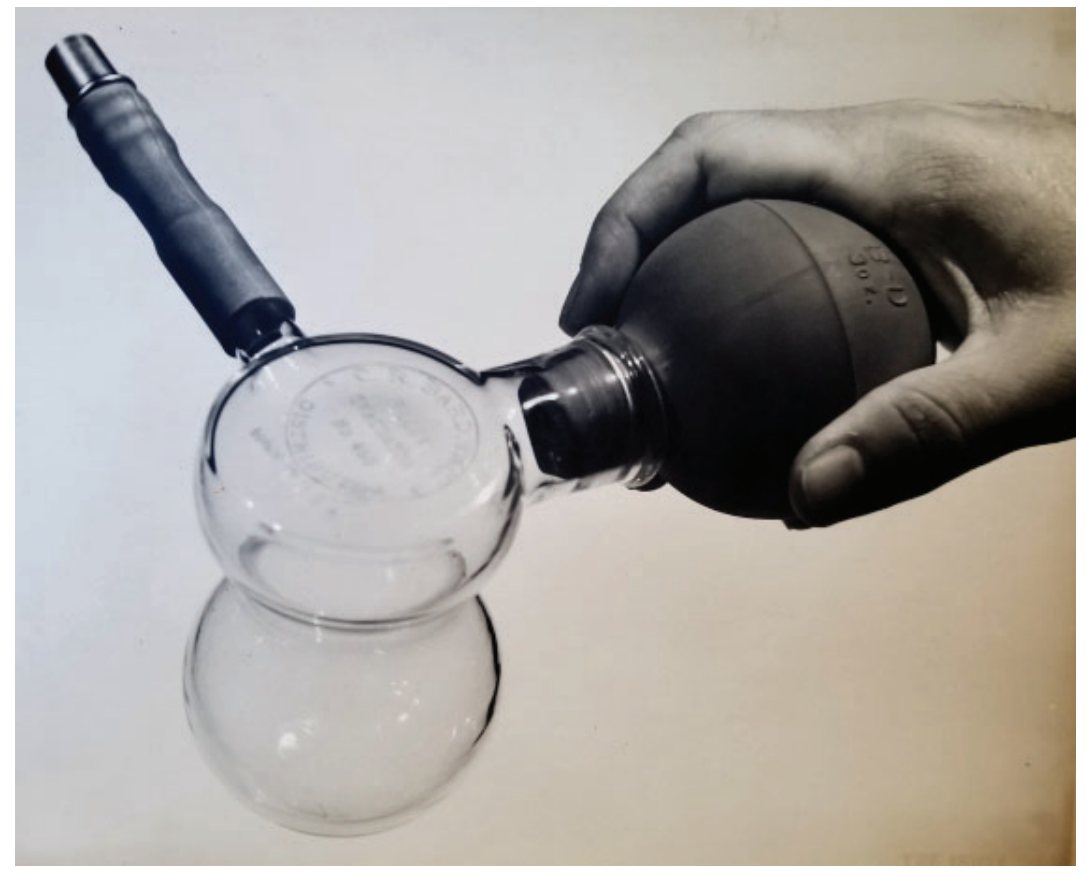

Figure 1. The Ellik evacuator, held by the inventor, and as originally appeared in 1937 (courtesy, The Ellik family)

his creative side4. He also had a predilection for theatre, where his comedic performance during the annual senior's play surprised his fellow classmates. Ellik's other activities included founding the Social Sciences Club to "promote interest in the study of government," and spearheaded the distribution of Christmas presents gifted from the students to the poor of the community. His high school yearbook described him as a "clever artist," who "wore a mean crease in his trousers."(4)

Following his high school graduation in 1925, Ellik worked as an assistant in a local pharmacy to put himself through college. The job piqued his interest in medicine and allowed him to complete a Graduate Degree in Pharmacy at the University of lowa in 1928, at age 23. Ellik strived for further education and gained admission to the University of lowa, School of Medicine, earning his M.D. in 1932. Ellik's family members recall that Milo originally had career aspirations in dermatology but, unable to find satisfaction in his work, switched to urology as he found the field "straightforward and predictable, and (one) can fix (its problems)".(3) This specialty ignited a passion for tinkering and innovation, redirecting his creative energy to bettering the field of urology.

Ellik trained under Dr. Nathan G. Alcock, who developed the urology program at the University of lowa in 1922, and Alcock's former resident, Dr. Rubin $\mathrm{H}$. Flocks. Alcock and Flocks worked together to collaborate on many innovations including a technique for transurethral resection of the prostate (TURP).(5) It was Alcock who urged Ellik to improve on designs of contemporary transurethral tools, such as the Davis evacuator. Ellik toiled in the chemistry department's glass-blowing shop to develop his first transurethral prototype evacuator.(6)(Figure 1) Ellik's simple, yet elegant design, with an upper and lower chamber, could be manipulated with one hand allowing for ease of use during TURP. The instrument did away with the valves and tubes of the Bigelow evacuator and allowed the urologist to continue a steady stream of flow between 'systole' and 'diastole', as Ellik termed the cycles, while allowing for tissue or chips to settle to the bottom of the chamber during diastole1. When first described, the evacuator found an immediate and enthused audience but Ellik himself did not pursue any monetary reward from the device. $(3,7)$ He deferred getting the U.S. patent for the invention which was eventually obtained by Bard in 1940.

Dr. Ellik completed his training in 1936 and moved to Long Beach, California where he married Edythe Carolyn Greene on December 25, 1937. (Figure 2, left) The Elliks went on to have 3 sons, the first of whom, Ron Ellik (1938-1968), became a science fiction writer. 
Dr. Ellik's third son passed away as a newborn but the middle son, Noel (1940-), became a poet and artist, and provided the authors with first hand insight into Ellik's life and family.

Dr. Ellik worked with Dr. George D. Stillson, and was an early member and leader of the LA Urological Society. (8) He was drafted into the Navy during World War II and served as Lieutenant Commander from 1942-1946 in the 73rd United States Naval Construction Battalion. Also known as the 'SeaBees', the construction battalions were deployed in the South Pacific and were widely known for their engineering prowess and ingenuity.(9) He continued to have a longitudinal relationship with the United States Naval Reserves, where he practiced as a civilian consultant for many years for the United States Naval Hospital and Fort MacArthur in Los Angeles, California.

Ellik gained success in his career and cared deeply about his patients but sometimes at the expense of his personal life. In 1945, after 8 years of practice, he and his wife separated. While they never officially divorced, they

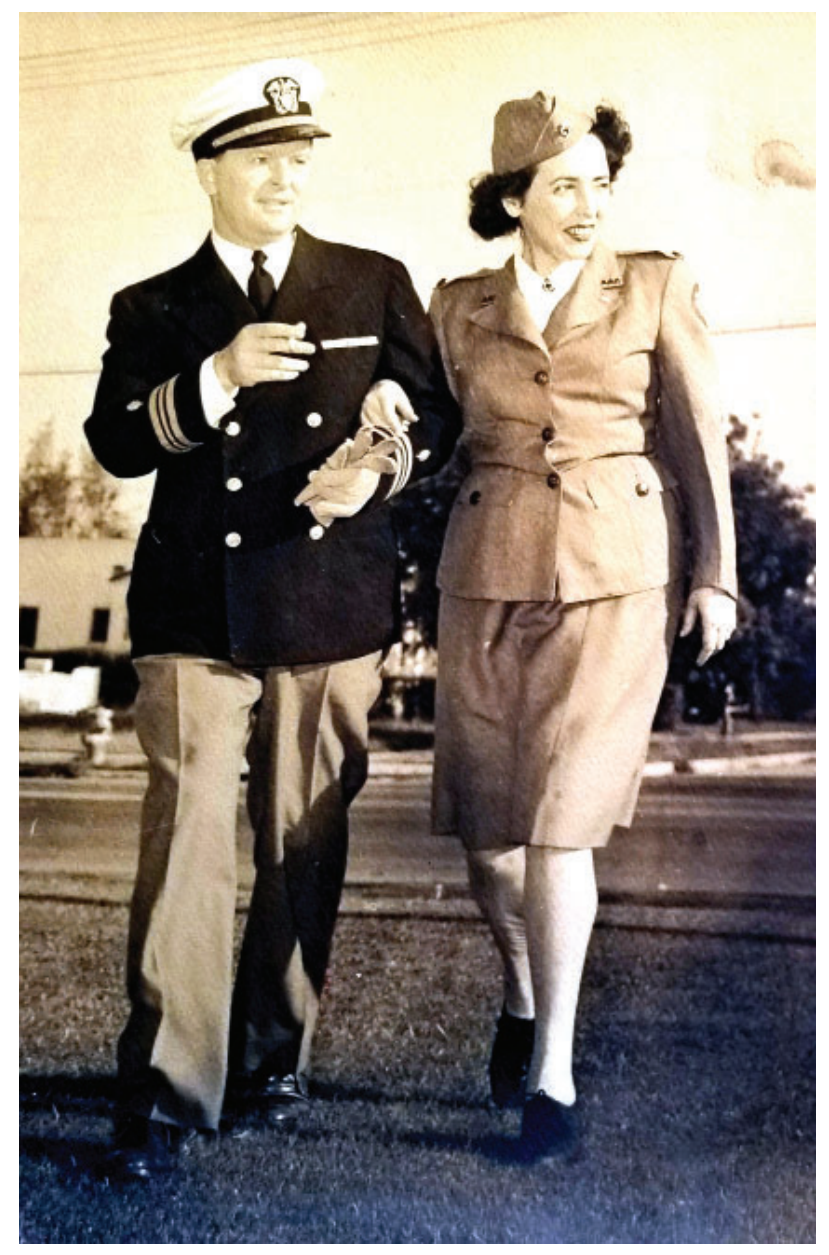

never reconciled and both moved on from the relationship. His children lived mostly with their mother but remember spending weekends with their father (Figure 2, right). The dissonance between his professional life and personal life only grew stronger as he returned from the military. His son recalls that his father was a "very quiet man, never heard anything about him..., only about war stories."(3) The stress of war, the drive for success, and passion for creativity weighed heavily on Ellik, who sometimes approached his personal life with a short temper and periodically drank to cope with these stressors.(3)

Dr. Ellik was a man of many interests and many careers, including time in pharmaceutical development, military work, and, his greatest passion, urology. One common theme that persisted throughout all of these fields, and throughout his entire life, was creativity and innovation. He developed ureteral loop stone baskets and manipulators, and meatotomy forceps, to name a few. At the 1971 Australasian Urological Society meeting, he showcased his last invention, the "Styptic Popsicle," a type of balloon

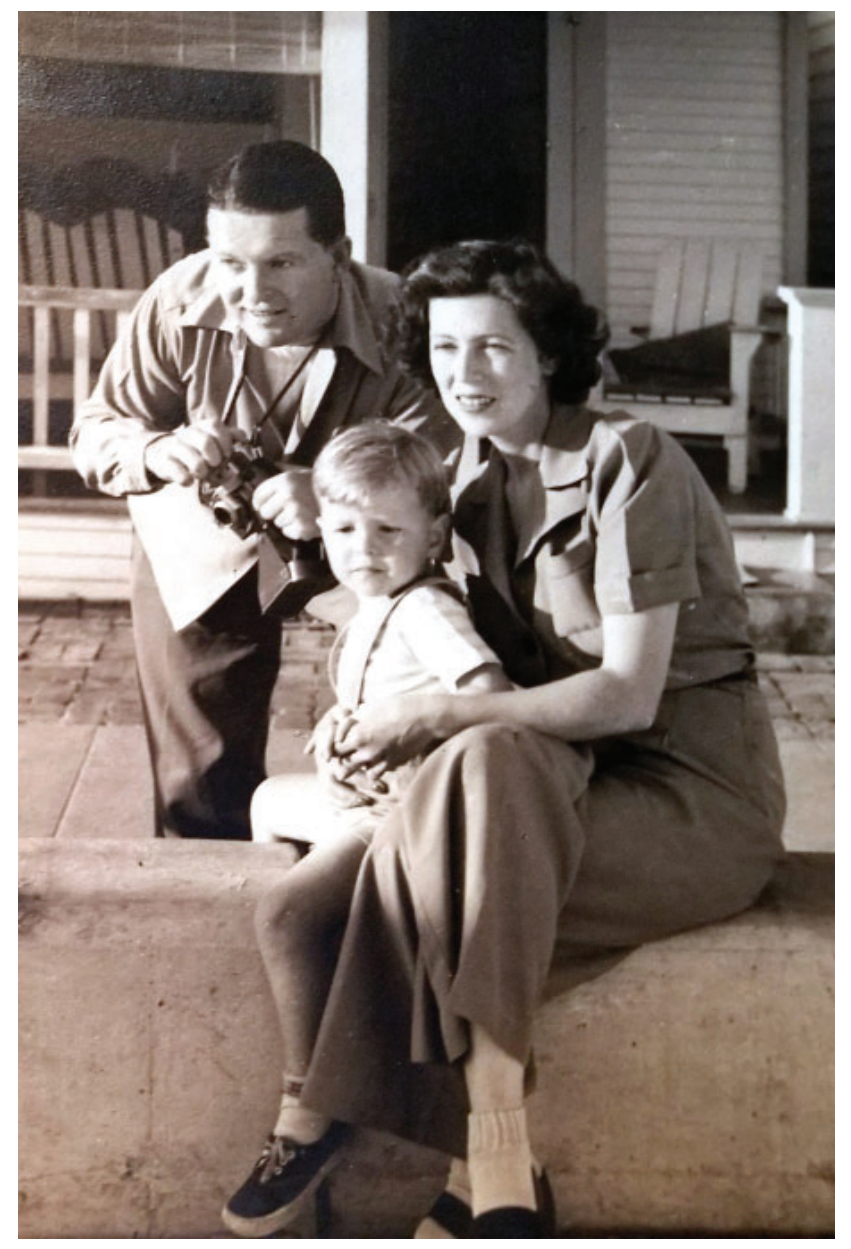

Figure 2. (Left) The Elliks during the Second World War, he as a Lieutenant Commander in the 73rd Seabees. (Right) The young Ellik family, Los Angeles, California, 1940s. (Courtesy, Noel Ellik) 


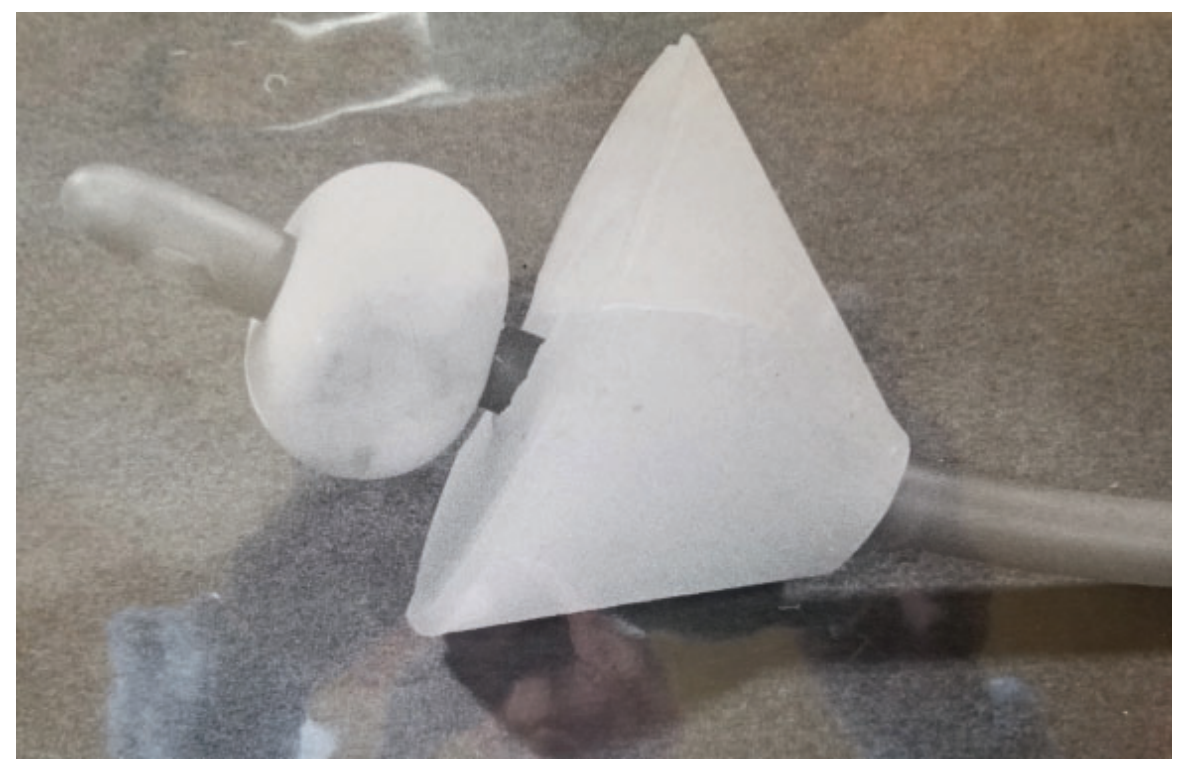

Figure 3. The Ellik "styptic popsicle" device, as presented at the 1971 Australasian Urologic Society and the Western Section of the American Urological Association (AUA). In Dr. Ellik's words, "a large Foley will pass through the lumen of (the) popsicle and almost any amount of inflation of the balloon provides a bolster for all types of traction. Using ice water to inflate the balloon will prolong the life of the popsicle. After the cone of ice 'self destructs' the balloon on the Foley should carry on some tamponade."(Courtesy Noel Ellik)

tamponade device that fit snug around a large Foley catheter and which would aid in tamponade after open simple prostatectomy.(Figure 3)

After a long career, Ellik passed away in 1979. He was a "quiet and private man," who was well-loved by his patients. His son, Noel Ellik, remembered that "people would live and die by every word he said. They thought he was one of the finest urologists in the world."(3)

\section{DISCUSSION}

Surgical instrumentation is continuously improved by innovators to achieve, safer more effective outcomes. Current surgeons benefit from the struggles of predecessors who provided us, through their experimentation and diligence, a better way to perform surgery. Across all fields of medicine there are many commonly used instruments known more by the eponymous name of their inventor than by the technical name itself. Indeed, it would be difficult to recognize a surgical table without an Adson clamp, a DeBakey forcep, a Mayo or Metzenbaum scissors, or a Balfour retractor.(10-12) We contacted the descendants of Milo Ellik to discover the person and the vision behind the Ellik evacuator, a mainstay of all transurethral surgery. Our oral history project revealed new photographs and inventions of Dr. Ellik which, as a result of the benevolence of the Ellik family, have been donated to the William Didusch Urology Museum.

The Ellik Evacuator remains an important tool of all urologists but non-urologists have also utilized its ease of use in gynecologic procedures. $(13,14)$

Ellik himself revered history and one's contributions to it. He wrote on the original concept of a bladder evacuator, lauding the idea first conceived by Bigelow in 1883, and credited Bigelow for the inspiration to develop his own evacuator.(7)

The Ellik family recalls he was driven by ingenuity, strived for improving the way things were done, and wasn't motivated by "making any money off of (the invention)".(3) By yielding the patent and subsequent 'ownership' of it, Ellik relied on his published works and the device's eponymous use by peers as his historical legacy.

Ellik's creativity never subsided but he also felt that surgical instrumentation had to be feasible and practical to be useful. He tried to solve the problem of post-prostatectomy bleeding using his ice 'popsicle' that could be adapted to any size Foley and would occupy the space of the prostatic fossa under traction, a kind of 'cryotherapy'. He also saw the limitations of current 'looped' stone extractors, methods of the early 20th century to remove ureteral stones by blind engagement within loops of wire or thread. $(15,16)$ Ellik's modification of the Balkus loop proved successful in removing 104 stones from 80 patients in a 5 1/2 month 
study and was adaptable to the pediatric population. (17) He was adamant that the surgeon could make such loops without the expense of commercialized products. He credited Thomas Moore (AUA President 1950-1951) with innovative surgery of the female diverticulum when reporting his own experience with ablative surgical techniques of the female diverticulum.(18)

Ellik's legacy lives on through his creativity and dedication to urology. That spirit of inquisitiveness and ingenuity still benefits patients of today.

\section{Conclusion}

The "Ellik Evacuator" has enjoyed widespread use since its invention by a urology resident in 1937, Milo Ellik (pronounced EE-lik), a creative innovator whose contributions to urology have quietly benefited generations of his successors.

\section{REFERENCES}

1. Ellik M: A Modification of the Evacuator. J Urol 1937; 38: 327.

2. Herr H: History of Transurethral Resection and Fulguration of Bladder Tumors. In: The History of Technologic Advancements in Urology. Edited by SR Patel, ME Moran, SY Nakada. Cham, Switzerland: Springer 2018.

3. Phone interview, Noel Ellik with author (BZ), 4/5/2020.

4. The Scroll. Boone, lowa: Boone High School 1925, (http:// boonesacheart.manriquez.net/bhs-1920s-yearbooks.html)

5. Hawtrey CE, Williams RD: Historical evolution of transurethral resection at the University of lowa: Alcock and Flocks. J Urol 2008; 180: 55.

6. Tasleem AM, Khan F, Mahmalji W et al: The Ellik Evacuator: Evolution in Emptying. Eur Urol Suppl 2014; 13: e328.

7. Ellik M: Henry Jacob Bigelow (1818-1890). Investigative Urology 1965; 3: 217.
8. Hendricks, ED: L.A. Urological Society True to Founders' Aim (https://laurological.org/about/history/)

9. The Story of the Seventy-Third United States Construction Battalion. Baton Rouge: Army and Navy Pictorial Publishers 1946.

10. Craig WM: Alfred Washington Adson-Pioneer Neurosurgeon, 1887-1951. J Neurosurgery 1952; 9: 117.

11. El-Sedfy A, Chamberlain RS: Surgeons and their tools: a history of surgical Instruments and their innovators--part I: place the scissors on the Mayo stand. Amer J Surg 2014; 80: 1089.

12. Eckman J: Donald Church Balfour, M.D. Lancet 1964; 84: 177.

13. Su Y, Huang K, Chuang F et al.: Use of an Ellik evacuator to remove tenacious bladder clots resulting from transvaginal oocyte retrieval: 2 cases and a literature review. Taiwanese J Obst Gyn 2019; 58: 880.

14. McArdle C, Feehily A, Allison KP: The Ellik evacuator. A modified technique for autologous fat collection during fat harvest. J Plastic Reconst Aesth Surg 2013; 5: 737.

15. Ellik M: The Looped Catheter Ureteral Stone Extractor: Perplexities in its Construction and Use. J Urology 1949; 61: 351.

16. Ellik M: Stones in the Ureter: Their Extraction by Looped Catheter. J Urol 1947; 57: 473.

17. Ellik M: Ureteral Calculi: Experiences in Looped Catheter Management. J Urology 1951; 65: 532.

18. Ellik M: Diverticulum of the Female Urethra: A New Method of Ablation. J Urology 1957; 77: 243. 